\title{
Aetiology Based Diagnosis and Treatment Selection in Intellectually Disabled People with Challenging Behaviours
}

\author{
Willem M.A. Verhoeven ${ }^{1,2, *}$ and Jos I.M. Egger ${ }^{1,3,4}$ \\ ${ }^{1}$ Vincent van Gogh Institute for Psychiatry, Centre of Excellence for Neuropsychiatry, Venray, The \\ Netherlands \\ ${ }^{2}$ Erasmus University Medical Centre, Department of Psychiatry, Rotterdam, The Netherlands \\ ${ }^{3}$ Donders Institute for Brain, Cognition and Behaviour, Radboud University Nijmegen, Nijmegen, The \\ Netherlands
}

${ }^{4}$ Behavioural Science Institute, Radboud University Nijmegen, Nijmegen, The Netherlands

\begin{abstract}
Since both intellectual disability and challenging behaviour are entities encompassing heterogeneous clinical conditions and current taxonomies are of limited use in this field of psychiatry, diagnosing psychiatric symptoms in intellectually disabled patients is still very complex. In the diagnostic process of psychiatric symptoms and behavioural abnormalities, the first step should be genome profiling using the latest techniques in order to detect pathogenic CNVs or single gene mutations that are causative for the developmental delay. Their importance can be derived from the scientific observation that several genetic syndromes are associated with a specific behavioural, psychiatric, neuropsychological or neurological symptom profile, relevant for both choice of treatment and prognosis. Second, it has to be stressed that psychiatric disorders, especially from the depression and anxiety spectrum, frequently manifest with atypical symptoms that may hamper adequate pharmacological treatment. With respect to challenging behaviours in general, it should be emphasized that these are essentially dependent on contextual variables for which no rational pharmacological treatment is available and behavioural interventions are primarily warranted. Prescription of psychotropics has been demonstrated to be marginally effective only and to induce regularly unwanted side effects or even an increase of abnormal behaviours. It is therefore recommended to measure always the plasma concentration of psychotropics and antiepileptics and to perform, preferably prior to the start of treatment, genotyping of relevant cytochrome isoenzymes.
\end{abstract}

In is concluded that, apart from the a priori genetic analysis, careful investigation of the here described data sources is needed to formulate a diagnostic hypothesis and treatment proposal.

Keywords: Psychiatric diagnosis, DSM, genetic etiology, psychotropics, pharmacogenetics, behaviour, behavioural phenotype.

\section{INTRODUCTION}

For psychiatry, genetic disorders form an intriguing challenge since they present a unique opportunity to study symptoms or symptom profiles in relation to a known aetiology and sometimes pathophysiology. As shown over the past decades, the search for candidate genes and copy number variations has increased the understanding of putative pathophysiological mechanisms underlying psychiatric disorders such as schizophrenia [1, 2], bipolar disorders [3], attention deficit disorder [4] and autism [5].

For all psychiatric disorders, categorical psychiatric taxonomies like the Diagnostic and Statistical Manual (DSM) of the American Psychiatric Association are routinely used for diagnosing which, however, often results in several 'diagnoses' at the same time. This phenomenon is called comorbidity. As stated for

*Address correspondence to this author at the Vincent van Gogh Institute for Psychiatry, Centre of Excellence for Neuropsychiatry, Stationsweg 46, 5803AC Venray, The Netherlands; Tel: +31 4785 27339; Fax: +31 4785 27110;

E-mail:wverhoeven@vvgi.nl,wmaverhoeven@planet.nl decades by several authors, such a nosological approach leads to diagnostic inflation with harmful side effects such as proliferation of new diagnoses and magnifying of comorbidity [6-8]. Moreover, the DSM system that was originally intended to create a common language may generate an epistemology of blindness that hinders the evolution of well founded diagnoses [9]. Finally, it should be emphasized that current psychiatric taxonomies are primarily tailored by consensus, not by empirics, and based on the presumption that a common pathophysiology underlies psychiatric categories.

As formulated by Lyketsos and colleagues, (neuro) psychiatry should operate bottom-up 'beginning with the emergence of pathology in the brain and attempting to understand the emerging of clinical syndromes out of this pathology' [10]. Such a bottom-up approach also needs a theoretical framework because, without theory, categories tend to increase as is illustrated by their growing number in subsequent DSM-versions [11, 12]. Clinical syndromes that arise from such a bottom-up orientation are not congruent with DSM categories but 
are reflections of a certain probability to develop a variety of psychiatric and neurocognitive symptoms [13].

The triviality of a top-down approach is best illustrated by the 'disorder' called mental retardation or intellectual disability (ID) that is not a disease or a disability but rather an essential phenomenon in a heterogeneous group of clinical conditions, ranging from genetic disorders to infectious diseases [14, 15]. In case of genetic disorders, the chance to define a phenotype is proportional to the prevalence of the disorder and the research efforts on its phenomenology and pathophysiology [13]. The same holds for emerging pharmacological treatment modalities that will be increasingly targeted not at DSM diagnoses but at functional impairments related to genetics and genomics crossing nosological boundaries $[16,17]$.

In the following, first, main ingredients will be outlined for an appropriate diagnostic process of neurocognitive and behavioural abnormalities as well as psychiatric symptoms in intellectually disabled patients. Second, a few examples of genetic syndromes with their variable levels of ID and their specific neuropsychiatric symptom profile, course and putative treatment regimens will be given. Finally, some future vistas will be discussed.

\section{PHASING THE DIAGNOSTIC PROCESS}

\section{Clarification}

In the majority of cases, challenging behaviours are the primary reason for psychiatric consultation $[18,19]$. To start with, results of recent psychological data, both cognitive and social emotional, as well as information about developmental and family history have to be collected. Since, with the exception of mood and anxiety disorders, the prevalence of psychiatric disorders in patients with ID is comparable to that in the general population [20, 21], instantaneous psychiatric labelling should be avoided. Instead, the diagnostic process should first continue with a functional analysis of the behaviour using detailed interviewing of primary care givers, preferably supported by video registration of the patient's behavioural repertoire. The latter can also be used to record phenotypical characteristics, especially dysmorphic features.

Subsequently, from the behavioural repertoire, essential elements can be discerned and specified by using e.g. the Aberrant Behaviour Checklist (ABC) [22,
23], the Diagnostic Assessment for the Severely Handicapped (DASH) [24, 25] and the Psychiatric Assessment Schedule for Adults with a Developmental Disability (PAS-ADD) [26, 27]. From these, cognitive and behavioural aspects of psychiatric disorders can be tentatively grouped into the symptomatic domains of motor activity, motivation, affect as well as thinking and perception [28].

The here described initial diagnostic phase translates the original referral question into a more circumscript plan of investigative actions.

\section{Additional Inquiries and Hypotheses}

Here, the first step has to be the diagnostic genome profiling with recent techniques since submicroscopic rearrangements are a common cause of ID $[29,30]$. In the past two decades, traditional karyotyping and molecular cytogenetic techniques such as fluorescence-in-situ-hybridization (FISH) and multiplex ligation-dependent probe amplification(MLPA), both with limited level of detection, have been replaced by array-based comparative genomic hybridization (array $\mathrm{CGH}$ [31, 32]. Genome wide array analysis may reveal etiologically relevant copy number variations (CNVs) while diagnostic exome sequencing aims to detect single gene mutations [33, 34].

Second, detailed information about developmental trajectory and family history has to be collected. These data may reveal a relapsing or deteriorating course as well as family load with psychiatric diseases, in particular (bipolar) affective disorders. The case history should also include information on the use of medication by the mother during pregnancy e.g. antiepileptics that may lead to ID with accompanying behavioural problems and somatic comorbidities [35]. In general, a substantial percentage of patients with ID are suffering from epilepsy for which treatment with antiepileptics is given. Special forms of epilepsy also exist, as is the case with gelastic seizures in hypothalamic hamartomas and the specific behavioural disturbances which these entail such as excessive laughing and crying as well as aggressive outbursts [36]. The use of antiepileptics may also give rise to behavioural and psychiatric symptoms e.g. psychosisinducing properties of levetiracetam and topiramate as well as confusional states induced by benzodiazepines [37]. Furthermore, it should be stressed that epileptic seizures are frequently associated with psychoses, both post- and interictal, and mood disorders [38] and that there exists an array of potential risk factors for 
ictally related psychoses, such as early age at epilepsy onset, history of prolonged febrile convulsions, and intellectual disability [39].

Moreover, since virtually no information exits about the bioavailability of psychotropics in patients with ID, measurement of plasma concentrations and identification of genetic polymorphisms of cytochromes P450 is strongly recommended [40, 41], especially in case of antiepileptic co-medication. Finally, it should be stressed that, in ID patients, a great variety of physical, medical and contextual conditions may present with behavioural problems only $[42,43]$.

With respect to the manifestation of psychiatric symptoms in ID patients, one should constantly be aware of atypical phenomena, in that e.g. depression frequently presents with a disturbed regulation of aggression and that episodic alterations of mood and behaviour which do not meet the criteria for bipolar disorder or cyclothymia, occur regularly [44] and should therefore be termed unstable mood disorder [45].

For the purpose of diagnostic hypothesis formulation, it should be underlined that ID and other brain disorders obviously affect the development of interpersonal contact and social as well as language skills, with lower levels of intellectual functioning generally associated with higher incidence of interpersonal contact problems. In ID populations, autism spectrum disorder (ASD) and attention deficit hyperactivity disorder (ADHD) are often wrongly classified since these 'diagnoses' are typically based on DSM-criteria without providing information regarding aetiology [46, 47].

\section{Clinical Decision Making}

Based on all available data from the former phases complemented by information from most recent literature, a psychiatric diagnosis may be formulated in one of the following forms: (a) classic psychiatric disorder with or without an atypical symptom profile [21]; (b) syndrome-specific psychiatric disorder e.g. bipolar disorder in Prader-Willi syndrome [48]; (c) psychiatric disorder related to underlying somatic/ neurological suffering e.g. cognitive-affective syndrome in Charlevoix-Saguenay ataxia [49]; (d) disinhibited behaviours due to environmental factors; or (e) drugrelated behavioural disorders. In case a genetic syndrome is associated with a specific cognitive, neurological or psychiatric profile, the term psychopathological or, more specific, neuropsychological, neurological or (neuro) psychiatric phenotype, can best be used. Once a diagnosis has been made, mostly, a targeted and personalized treatment design can be formulated.

\section{PSYCHOPATHOLOGICAL PHENOTYPES: SOME EXAMPLES}

\section{2q11.2 Microdeletion (22q11.2DS;OMIM:192430)}

This is the most common microdeletion syndrome formerly called Velo-Cardio-Facial Syndrome, with a highly variable phenotype. Its behavioural phenotype, including the psychopathological features and endocrine dysfunctions, especially hypoparathyroidism, was originally described by the speech therapist Robert Shprintzen [50]. Over subsequent years it became apparent that 22q11DS is highly associated with symptoms from the schizophrenia, bipolar, anxiety and autistic spectrum $[51,52]$. With respect to the neuropsychological phenotype, it has been shown that deficits in problem solving and planning as well as in abstract and social thinking are most prominent [53]. It has to be stressed, however, that psychiatric symptoms from the affective, obsessive-compulsive and psychotic domains originate from the discrepant intellectual profile and impaired visuoperceptual abilities with a diminished comprehension of abstract and symbolic language [54]. Although Schneider and co-workers recently mentioned the persistence of negative psychotic symptoms in 22q11DS [55], it should be underlined that these phenomena may also stem from the neurocognitive dysfunctions.

Apart from the above mentioned neuropsychiatric and neuropsychological sequellae, it has become obvious that the 22q11.2 microdeletion syndrome, from approximately the age of forty, shows, in a minority of cases, a deteriorating course with Parkinsonian symptoms [56, 57].

Concerning the treatment regimen, a distinction should be made between pharmacological and nonpharmacological strategies. First, of course, endocrine dysfunctions have to be corrected since they may mimic psychotic features. Second, it has been repeatedly demonstrated that psychotic symptoms in 22q11.2DS do not respond to classical antipsychotics, including risperidone, whereas results from case descriptions suggest that some atypical antipsychotics may be effective in reducing psychotic symptoms (Table 1). In case of Parkinsonian symptoms, some alleviation may be achieved upon treatment with L- 
Table 1: Atypical Psychosis in Patients with del22q11: Putative Treatment Strategies

\begin{tabular}{|c|c|c|c|c|c|}
\hline Case report & $\begin{array}{l}\text { Sex/Age } \\
(y ; m)\end{array}$ & $\begin{array}{l}\text { Antipsychotic Daily } \\
\text { Dose }\end{array}$ & Co-Medication & Results & Remarks \\
\hline $\begin{array}{c}\text { Gladston \& Clarke } \\
(2005) \\
{[122]}\end{array}$ & male/32 & clozapine $300 \mathrm{mg}$ & $\begin{array}{c}\text { sodium valproate } \\
1200 \mathrm{mg}\end{array}$ & $\begin{array}{l}\text { Marked reduction of } \\
\text { psychotic symptoms }\end{array}$ & $\begin{array}{l}\text { Constipation and hypersalivation; } \\
\text { myoclonic epilepsy without } \\
\text { history of epilepsy }\end{array}$ \\
\hline $\begin{array}{c}\text { Briegel (2007) } \\
{[123]}\end{array}$ & male/12;10 & clozapine $450 \mathrm{mg}$ & none & $\begin{array}{l}\text { Significant reduction } \\
\text { of psychotic } \\
\text { symptoms }\end{array}$ & $\begin{array}{l}\text { No improvement and severe } \\
\text { extrapyramidal side-effects on } \\
\text { haloperidol; clozapine stopped } \\
\text { because of seizures }\end{array}$ \\
\hline $\begin{array}{c}\text { Krahn et al. (1998) } \\
\text { [124] }\end{array}$ & male/30 & clozapine 125mg (?) & phenytoin $200 \mathrm{mg}$ & $\begin{array}{l}\text { Medically stable } \\
\text { condition }\end{array}$ & $\begin{array}{l}\text { No effect of and extrapyramidal } \\
\text { side effects on fluphenazine; }\end{array}$ \\
\hline $\begin{array}{c}\text { Yacoub \& Aybar } \\
\text { (2007) [125] }\end{array}$ & female/25 & clozapine $75 \mathrm{mg}$ & $\begin{array}{c}\text { sodium valproate } \\
750 \mathrm{mg}\end{array}$ & $\begin{array}{c}\text { Full recovery of } \\
\text { psychosis }\end{array}$ & $\begin{array}{l}\text { Initially seizures; no effect of } \\
\text { olanzapine, aripiprazole, } \\
\text { ziprasidone and perphenzaine }\end{array}$ \\
\hline $\begin{array}{l}\text { Gagliano \& Masi } \\
\text { (2009) [126] }\end{array}$ & female/7; 1 & $\begin{array}{l}\text { aripiprazole } 15 \mathrm{mg} \\
\text { plus clozapine } \\
150 \mathrm{mg}\end{array}$ & none & $\begin{array}{c}\text { Dramatic } \\
\text { improvement of } \\
\text { psychotic symptoms }\end{array}$ & $\begin{array}{l}\text { Nonresponsive to risperidone } \\
\text { and aripiprazole monotherapy }\end{array}$ \\
\hline $\begin{array}{l}\text { Sporn et al. }(2004) \\
\text { ( four cases) [127] }\end{array}$ & unknown & $\begin{array}{l}\text { clozapine or } \\
\text { olanzapine or } \\
\text { quetiapine }\end{array}$ & none & $\begin{array}{l}\text { Good clinical } \\
\text { response }\end{array}$ & $\begin{array}{c}\text { Epileptiform EEG } \\
\text { changes/seizures in three } \\
\text { patients }\end{array}$ \\
\hline $\begin{array}{c}\text { Müller \& Fellgiebel } \\
(2008) \\
{[128]}\end{array}$ & female/41 & $\begin{array}{l}\text { quetiapine } 300- \\
400 \mathrm{mg}\end{array}$ & none & $\begin{array}{l}\text { Free of psychotic } \\
\text { symptoms }\end{array}$ & No side-effects \\
\hline $\begin{array}{c}\text { Lin et al. (2010) } \\
\text { [129] }\end{array}$ & female/16 & $\begin{array}{l}\text { aripiprazole } 10- \\
25 \mathrm{mg}\end{array}$ & $\begin{array}{c}\text { calcium } 1500 \mathrm{mg} \\
\text { plus calciferol } \\
0,25 \mu \mathrm{g}\end{array}$ & $\begin{array}{l}\text { Free of psychotic } \\
\text { symptoms }\end{array}$ & $\begin{array}{l}\text { Hypoparathyroidism; no side- } \\
\text { effects }\end{array}$ \\
\hline $\begin{array}{c}\text { Carandang \& } \\
\text { Scholten (2007) } \\
{[130]}\end{array}$ & male/17 & metyrosine $1000 \mathrm{mg}^{*}$ & none & $\begin{array}{l}\text { Significant functional } \\
\text { improvement }\end{array}$ & No response on aripiprazole \\
\hline
\end{tabular}

Note. ${ }^{*}$ Competitive inhibitor of the enzyme tyrosinehydroxylase.

dopa [57]. Most important, however, is a contextual psychological treatment that guaranties a safe, well known and structured environment, where possible directed at the impaired capacity to estimate intentions, emotions and behaviours of others [58, 59].

\section{Distal 22q11 Microdeletionsyndrome (OMIM: 611867)}

Here, the microdeletion is located distal to the common $\sim 3 \mathrm{Mb}$ deletion as seen in 22q11DS. In contrast to the classical 22q11.2 microdeletion syndrome, facial dysmorphisms, cognitive and behavioural problems as well as psychiatric symptoms are typically less pronounced. With respect to somatic comorbidity, a wide range of congenital heart defects have been described extending the cardiac phenotypical range [60]. When the 22q11 distal deletion includes the SMARCB1 gene, an increased risk is present on the development of malignant rhabdoid tumor [61]. In some patients with distal 22q11 microdeletion syndrome, symptoms from the anxiety cluster have been reported that may be pathophysiologically connected to the absence of the
MAPK1 gene which is accompanied by a disordered neurobiological stress homeostasis. Treatment with an antidepressant such as citalopram may then lead to full remission of anxiety symptoms [62]

\section{7q21.31 Microdeletion Syndrome (Koolen-De Vries Syndrome; OMIM:610443)}

This microdeletion syndrome was first described genotypically by Koolen and colleagues and thought to be caused by an interstitial deletion in 17q21.31, comprising the MAPT gene. Subsequently, they reported the somatic abnormalities of which facial dysmorphisms, central nervous system anomalies, and congenital heart and/or kidney defects are most prominent [63]. Nowadays, the KANSL1 gene (17q31.31) has been demonstrated to be causative for the phenotype [64]. Given its monogenic aetiology, the syndrome was re-termed as Koolen-De Vries syndrome. With respect to the behavioural phenotype, in addition to intellectual disability, an amiable, friendly disposition was described [65]. Cognitive phenotyping of a small number of patients disclosed hypersociability accompanied by high levels of frustration tolerance to 
form the core of the neuropsychological phenotype [66]. Such a profile is to some extent comparable to that observed in Angelman syndrome and Williams syndrome and therefore, Koolen-De Vries syndrome should be included in their differential diagnosis.

\section{9q Subtelomere Deletion Syndrome (Kleefstra Syndrome; OMIM:610253)}

Kleefstra syndrome, originally termed $9 q$ subtelomeric deletion syndrome, is in the majority of cases caused by a microdeletion in chromosomal region 9q34.3 [67] and in some by a mutation in the euchromatin histione methyltransferase 1 (EHMT1) gene $[68,69]$. In all cases, however, loss of function of the EHMT1 gene is the causative factor. Its core phenotype comprises developmental delay/intellectual disability, hypotonia and distinct facial dysmorphisms, and may be associated with congenital heart and/or renal defects and epilepsy [70]. The behavioural phenotype of Kleefstra syndrome constitutes particular sleep disturbances, characterized by frequent awakenings and daytime sleepiness, and marked loss of activity [71]. With respect to course, it has been demonstrated that the severity of behavioural and motor deficiencies such as fixed flexure of arms and hands, increases over time and debutes after adolescence, pointing at a neurodegenerative pattern [72]. Over time, reduced motor activity, markedly restricted social interactions and minimal to absent behavioural initiative and emotional responsivity become most prominent, a cluster of symptoms that meets the criteria for the syndrome of apathy. This constellation of motor and emotional features may easily be misdiagnosed as either mood disorder [73] or catatonia [74]. It is understandable, therefore, that treatment with antidepressants or benzodiazepines cannot be effective.

\section{Beta-Propeller Protein Associated Neurodegen- eration (BPAN; OMIM:300894)}

Neurodegeneration with brain iron accumulation (NBIA) comprises an array of progressive brain disorders presenting with neurological and psychiatric symptoms, sometimes accompanied by intellectual impairment and behavioural problems. Originally, the neuropathologists Hallervorden and Spatz described in 1922 a typical phenotype characterized neurologically by movement disorders and pathologically by iron accumulation in the basal ganglia [75]. Since the late sixties of the past century, several progressive movement disorders with iron excess in different parts of the basal ganglia have been described that, with the introduction of brain magnetic resonance imaging techniques, could be further differentiated and can clinically be subdivided into two major groups: early onset / rapid deterioration, and late onset / slow deterioration [76].

NBIA has to be suspected when brain MRI findings point at abnormal iron accumulation in the basal ganglia, particularly globus pallidus or substantia nigra, in combination with dystonia and Parkinsonism. Until recently, seven genetic types of NBIA could be identified, of which six are inherited in an autosomal recessive and one in an autosomal dominant way.

Recently, Kruer and co-workers [77] described a novel NBIA showing an additional specific neuroimaging pattern in the substantia nigra together with global cerebral atrophy. Clinically, this NBIA is different than the other types and does not fit within the aforementioned subdivision into two groups. Here, the disease starts with early childhood intellectual impairment that remains static during several decades after which progressive cognitive decline occurs and neurological symptoms emerge, especially dystonia and Parkinsonism, and therefore termed Static Encephalopathy of childhood with Neurodegeneration in Adulthood (SENDA). Shortly thereafter, it became clear that this condition is caused by de novo heterozygous mutations in the WD repeat-containing protein 45 (WDR45) gene (OMIM:300526) located in Xp11.23 [78]. Given the specific properties of the protein encoded by WDR45, the name Beta-propeller Protein Associated Neurodegeneration (BPAN) was suggested to be most appropriate [79, 80]. Nowadays, it has been demonstrated that the clinical phenotype of this X-linked dominant NBIA disorder is in its early phase characterized by developmental delay and intellectual disability, and frequently associated with epileptic seizures. The second phase, generally starting in the second or third decade, is clinically dominated by progressive cognitive and motor deterioration with prominent dystonia and Parkinsonian symptoms, ultimately leading to dementia [81].

Since in the beginning of the second phase, symptoms from the apathetic/autistic and anxiety/mood spectrum may be present, these can be wrongly diagnosed as a depressive disorder instead of contingent upon the symptom profile in patients with early stages of Parkinson's disease. Therefore, antidepressants will not be effective. Treatment with Levodopa/carbidopa in patients with BPAN may result in temporal or partial effects on motor function [79, 82]. 


\section{Lysosomal Disease}

Although metabolic disorders generally debute at early age, some of these may start in late adolescence or early adulthood. In case of lysosomal disease such as Niemann-Pick type C (mutation NPC1 gene; 18q11.2 [OMIM:257220] or NPC2 gene; 14q24.3 [OMIM:607625]) a late onset presentation may, apart from pre-existing (mild) developmental delay, manifest firstly with a schizophrenia-like psychosis with or without catatonic symptoms [83, 84]. Another example is mucopolysaccharidosis type IIIB (MPSIIIB; Sanfilippo B; OMIM: 252920) that is caused by a mutation in the NAGLU gene (17q21.1; OMIM: 609701) resulting in a deficiency of $\mathrm{N}$-acetyl- $\alpha$-D-glucosaminidase. MPSIIIB is characterized by later onset developmental delay followed by slow progressive dementia starting from the fourth decade $[85,86]$. These two lysosomal diseases do not present with specific dysmorphisms and can therefore be easily misdiagnosed as either late onset schizophrenia or early onset Alzheimer's dementia.

\section{DISCUSSION AND CONCLUSIONS}

In this paper, the difficulties in the diagnostic process and the choice for rational treatment strategies in intellectually disabled patients with challenging behaviours and/or neuropsychiatric symptoms are presented. Because of the regular co-occurrence of psychiatric and/or neurological symptoms in this group of patients, some examples of genetic syndromes are given that are characterized by a psychopathological and/or neurological phenotype.

As mentioned previously, psychiatric symptoms may originate in the context of a traditional psychiatric disorder that presents frequently with an atypical symptomatology like disinhibited behaviours and/or self-injuries, or as part of a so called psychopathological phenotype. Moreover, a psychiatric disorder may be related to an underlying somatic/neurological disease. In addition, both challenging behaviours and psychiatric symptoms may be drug-related (e.g. antiepileptics and psychotropics). Finally, disinhibited behaviours frequently arise as a result of environmental factors.

As known for several decades, both depressive diseases and anxiety disorders frequently manifest with either pronounced irritability, perseverative/compulsive behaviours and motoric signs, or an exacerbation of challenging behaviours, and are therefore often symptomatically treated with antipsychotics instead of with antidepressants [87-89]. Concerning antidepressant medications, it has been shown that these compounds, particularly SSRIs, reduce symptoms in only half of the patients [90]. When depressive symptoms occur in the context of a so called unstable mood disorder or a bipolar affective disorder, treatment with antiepileptics, preferably valproic acid is the method of choice [45, 91].

By using categorical diagnostic systems, repetitive/stereotyped and/or disinhibited behaviours may easily meet the criteria for autism spectrum disorder (ASD) or attention deficit hyperactivity disorder (ADHD). Although some beneficial effects of atypical antipsychotics, especially risperidone and aripiprazole, on autistic symptoms (i.e., irritability and repetition) have been reported [92, 93], systematic reviews could not substantiate this claim for either risperidone or aripiprazole [94, 95]. This holds, a fortiori, for ADHD [96]. As reported recently, for the treatment of ADHD in intellectually disabled patients in whom anxiety disorders or severe tics are frequently also present, the selective noradrenaline reuptake inhibitor amoxetine should be preferred [97].

In case of challenging behaviours in general, prescription of neuroleptics, particularly second generation antipsychotics, has been demonstrated to be only marginally effective [98, 99]. It should be stressed that such treatments are regularly accompanied by unwanted side effects especially significant weight gain and the development over time of dislipidemia and/or diabetes mellitus, subsumed under the term metabolic syndrome $[100,101]$.

With respect to psychopathological phenotypes, it has become obvious that certain genetic syndromes can be characterized by their specific psychiatric or neuropsychological profile like e.g. 22q11.2 microdeletion syndrome and Koolen-De Vries syndrome. In those cases, routine pharmacological treatments are generally ineffective. For some syndromes, such as Prader-Willi syndrome, a circumscript subset of recurrent affective/psychotic symptoms may occur, especially when the aetiology is a maternal uniparental disomy. These patients develop, starting in their late adolescence, a subacute polymorphous psychosis with a symptom profile that meets the criteria for cycloid psychosis [102-106]. In some cases, an increase of psychomotor symptoms dominates the psychoticsyndrome resembling catatonia [107]. After several relapses with generally full recovery, course and 
symptomatology overlap that of a bipolar affective disorder and the psychosis should therefore be treated primarily with mood stabilizing agents e.g. Lithium or valproic acid $[54,108]$.

As can be inferred from the aforementioned, the contribution of psychopharmacological agents to the reduction of ID-related behavioural problems and psychiatric symptoms is relatively poor. This is affirmed by the results of the only placebo controlled study with haloperidol and risperidone showing the largest effect on challenging behaviours of placebo [109]. Furthermore, controlled discontinuation of antipsychotics prescribed for behavioural symptoms over multiple years has demonstrated improved behavioural functioning and amelioration of metabolic parameters [110-112]. In fact, challenging behaviours may even be the first and only manifestation of motor or autonomic side effects of psychotropics e.g. acathisia [42].

Given the frequent polymedication in ID patients and the absence of reliable data on plasma concentration-effect relationship of psychotropics in this group of patients, it is highly recommended to measure the plasma concentration of antipsychotics, antidepressants and antiepileptics and, if applicable, their active or toxic metabolites. As mentioned before, the latter is of special importance since the clinical impact is influenced by the genetically determined capacity of the cytochrome P450 (CYP) isoenzym system, in particular CYPs 2D6, 2C9 and 2C19. It should be noticed that CYP 2D6 and CYP 2C19 are responsible for metabolizing a range of antipsychotics and antidepressants, and polymorphism for these enzymes may result in ultra rapid or poor biotransformation which, in turn, defines effect and toxicity $[40,113,114]$. CYPgenotyping prior to the prescription of psychotropics especially in case of co-medication with antiepileptics has therefore always to be considered.

Since challenging behaviours are essentially dependent on environmental variables and no rational psychopharmacological treatment is available for such behaviours, again, functional re-analysis of the behavioural history is needed in order to define appropriate psychological and/or behavioural interventions. To this end, several treatment programs based on operant learning and cognitive models with documented efficacy can be employed such as differential reinforcement strategies (e.g. to reduce inappropriate vocalisations), low level problem solving, assertiveness and goal management training [115118]. In certain genetic disorders like Noonan syndrome and Turner syndrome, specific impairments in affective information processing and social interaction can be identified and may be modulated by means of targeted social-cognitive training [119-121].

In conclusion, from the here presented data, it has become obvious that a careful investigation and analysis of abnormal behaviours in patients with ID is essential for establishing an appropriate diagnostic process leading to a diagnostic hypothesis with a subsequent, individually targeted, treatment program including regular evaluation of effectiveness and potential side effects. This holds particularly for some genetic syndromes that may be accompanied with a specific set of behavioural, psychiatric or neurological symptoms that may be of major clinical relevance for prognosis. Albeit that psychotropics may be effective in the treatment of psychiatric symptoms and useful for alleviating challenging behaviours in patients with intellectual disabilities, behavioural interventions have to be employed where possible, and effectiveness as well as side effects of psychopharmacological interventions should be monitored regularly.

\section{REFERENCES}

[1] Modinos G, Lyegbe C, Prata D, et al. Molecular genetic gene-environment studies using candidate genes in schizophrenia: a systematic review. Schizophr Res 2013; 150: 356-65.

http://dx.doi.org/10.1016/j.schres.2013.09.010

[2] Costain G, Lionel AC, Merico D, et al. Pathogenic rare copy number variants in community-based schizophrenia suggest a potential role for clinical microarrays. Hum Mol Genet 2013; 22: 4485-501.

http://dx.doi.org/10.1093/hmg/ddt297

[3] Seifuddin F, Belmonte Mahon P, Judy J, et al. Meta-analysis of genetic association studies on bipolar disorder. Am J Med Genet B Neuropsychiatr Genet. 2012; 159B: 508-518.

http://dx.doi.org/10.1002/ajmg.b.32057

[4] Elia J, Sackett J, Turner $\mathrm{T}$, et al. AttentionDeficit/Hyperactivity Disorder genomics: update for clinicians. Curr Psychiatry Rep 2012; 14: 579-89. http://dx.doi.org/10.1007/s11920-012-0309-4

[5] Verhoeven WMA, Egger JIM, Feenstra I. Autism and genetic syndromes. In: Deutsch SI, Urbano MR, editors. Autism spectrum disorders: the role of genetics in diagnosis and treatment. Vienna: In Tech 2011; p 31-48. http://dx.doi.org/10.5772/19161

[6] Westen D. Prototype diagnosis of psychiatric syndromes. World Psychiatry 2012; 11: 16-21. http://dx.doi.org/10.1016/j.wpsyc.2012.01.004

[7] Peters ME, Taylor J, Lyketsos CG, Chisolm MS. Beyond the DSM: the perspectives of psychiatry to patients. Prim Care Companion CNS Disord 2012. http://dx.doi.org/10.4088/PCC.11m01233

[8] Batstra L, Frances A. Diagnostic inflation. Causes and a suggested cure. J Nerv Ment Dis 2012; 200: 474-9. http://dx.doi.org/10.1097/NMD.0b013e318257c4a2

[9] Hyman SE. The diagnosis of mental disorders: the problem of reification. Ann Rev Clin Psychol 2010; 6: 155-79. http://dx.doi.org/10.1146/annurev.clinpsy.3.022806.091532 
[10] Lyketsos CG, Kozauer N, Rabens PV. Psychiatric manifestations of neurological disease: where are we headed? Dialogues Clin Neurosci 2007; 9: 111-23.

[11] Egger JIM, de Mey H, Janssen G. Assessment of executive functioning in psychiatric disorders: functional diagnosis as the outcome of treatment. Clin Neuropsychiatry 2007; 4: 111-6.

[12] Frances A. The past, present and future of psychiatric diagnosis. World Psychiatry 2013; 12: 111-2.

http://dx.doi.org/10.1002/wps.20027

[13] Verhoeven WMA, Tuinier S, van der Burgt I. Top-down or bottom-up: contrasting perspectives on Psychiatric diagnoses. Biologics: Targets \& Therapy 2008; 2: 409-17.

[14] Salvador-Carulla L, Reed GM, Vaez-Azizi LM, et al. Intellectual developmental disorders: towards a new name, definition and framework for "mental retardation/intellectual disability" in ICD-11. World Psychiatry 2011; 10: 175-80.

[15] Van Karnebeek CDM, Stockler S. Treatable inborn errors of metabolism causing intellectual disability: a systematic literature review. Mol Genet Metab 2012; 105: 368-81. http://dx.doi.org/10.1016/j.ymgme.2011.11.191

[16] Maier W, Zobel A. Contribution to allelic variations to the phenotype of response to antidepressants and antipsychotics. Eur Arch Psychiatry Clin Neurosci 2008; 258(Suppl 1): 12-20.

http://dx.doi.org/10.1007/s00406-007-1004-z

[17] Harrison PJ. The current impact of genetics and genomics on neuropsychopharmacology. Eur Neuropsychopharmacol doi: 10.1016/j.euroneuro. 2013.02.005.

[18] McCarty J, Hemmings C, Kravatrin E, et al. Challenging behavior and co-morbid psychopathology in adults with intellectual disability and autism spectrum disorders. Res Dev Disabil 201; 31: 362-6.

[19] Lundqvist LO. Prevalence and risk markers of behaviour problems among adults with intellectual disabilities: a total population study in Örebro county. Res Dev Disabil 2013; 34: 1346-56. http://dx.doi.org/10.1016/j.ridd.2013.01.010

[20] Cooper SA, Smiley E, Morrison J, Williamson A, Allan L. An epidemiological investigation of affective disorders with a population-based cohort of 1023 adults with intellectual disabilities. Psychol Med 2007; 37: 873-82. http://dx.doi.org/10.1017/S0033291707009968

[21] Buckles J, Luckasson R, Keefe E. A systematic review of the prevalence of psychiatric disorders in adults with intellectual disability, 2003-2010. J Mental Health Res Intellect Disabil 2013; 6: 181-207.

http://dx.doi.org/10.1080/19315864.2011.651682

[22] Aman MG, Burrow WH, Wolford PL. The Aberrant Behavior Checklist-Community: factor validity and effect of subject variables for adults in group homes. Am J Ment Retard 1995; 100: 283-92.

[23] Hill J, Pwolitch S, Furniss F. Convergent validity of the aberrant behaviour checklist and behaviour problems inventory with people with complex needs. Res Develop Disabil 2008; 29: 45-60.

http://dx.doi.org/10.1016/j.ridd.2006.10.002

[24] Matson JL, Gardner WI, Coe DA, Sovner R. A scale for evaluating emotional disorders in severely and profoundly mentally retarded persons. Development of the Diagnostic Assessment for the Severely Handicapped (DASH) scale. $\mathrm{Br}$ J Psychiatry 1991; 159: 404-9.

http://dx.doi.org/10.1192/bjp.159.3.404

[25] Paclawskyj T, Matson JL, Bamburg JW, Baglio CS. A comparison of the Diagnostic Assessment for the Severely Handicapped-II (DASH-II) and the Aberrant behaviour Checklist (ABC). Res Dev Disabil 1997; 18: 289-98. http://dx.doi.org/10.1016/S0891-4222(97)00010-3

[26] Moss S, Prosser $\mathrm{H}$, Costillo $\mathrm{H}$, et al. Reliability and validity of the PAS-ADD checklist for detecting psychiatric disorders in adults with intellectual disability. J Intellect Disabil Res 1998; 42: 173-83.

http://dx.doi.org/10.1046/j.1365-2788.1998.00116.x

[27] Allan D, Lowe K, Matthews H, Anness Y. Screening for psychiatric disorders in a total population of adults with intellectual disability and challenging behaviour using the PASADD checklist. J Appl Res Intellect Disabil 2012; 25: 342-9. http://dx.doi.org/10.1111//.1468-3148.2011.00670.x

[28] Verhoeven WMA, Tuinier S. Neuropsychiatric consultation in mentally retarded patients: a clinical report. Eur Psychiatry 1997; 1: 242-8.

http://dx.doi.org/10.1016/S0924-9338(97)83298-1

[29] Battaglia A, Carey JC. Diagnostic evaluation of developmental delay/mental retardation: and overview. Am J Med Genet 2003; 177C: 3-14. http://dx.doi.org/10.1002/ajmg.c. 10015

[30] Rauch A, Hoyer J, Guth S, et al. Diagnostic yield of various genetic approaches in patients with unexplained developmental delay or mental retardation. J Med Genet 2006; 140A: 2063-74. http://dx.doi.org/10.1002/ajmg.a.31416

[31] Pinkel D, Segraves R, Sudar D, et al. High resolution analysis of DNA copy number variation using comparative genome hybridization to microarrays. Nat Genet 1998; 20: 207-11. http://dx.doi.org/10.1038/2524

[32] Veltman JA. Genomic microarrays in clinical diagnosis. Curr Opin Pediatr 2006; 18: 598-603.

http://dx.doi.org/10.1097/MOP.0b013e3280105417

[33] De Ligt J, Willemsen MH, van Bon BWM, et al. Diagnostic exome sequencing in persons with severe intellectual disability. N Engl J Med 2012; 376: 1921-9. http://dx.doi.org/10.1056/NEJMoa1206524

[34] Gilissen C, Hehir-Kwa JY, Tjwan Thung D, et al. Genome sequencing identifies major causes of severe intellectual disability. Nature 2014. http://dx.doi.org/10.1038/nature13394

[35] Tomson T, Battino D. Teratogenic effects of antiepileptic drugs. Lancet Neurol 2012; 11: 803-13. http://dx.doi.org/10.1016/S1474-4422(12)70103-5

[36] Veendrick-Meekes MJBM, Verhoeven WMA, van Erp MG, van Blarikom W, Tuinier S. Neuropsychiatric aspects of patients with hypothalamic hamartomas. Epilepsy Behav 2007; 11: 218-21.

http://dx.doi.org/10.1016/j.yebeh.2007.03.005

[37] Weintraub D, Buchsbaum R, Resor Jr SR, Hirsch LJ. Psychiatric and behavioral side effects of the newer antiepileptic drugs in adults with epilepsy. Epilepsy Behav 2007; 10: 105-10.

http://dx.doi.org/10.1016/j.yebeh.2006.08.008

[38] Gaitatzis A, Trimble MR, Sander JW. The psychiatric comorbidity of epilepsy. Acta Neurol Scand 2004; 110: 207-20. http://dx.doi.org/10.1111/j.1600-0404.2004.00324.x

[39] Irwin LG, Fortune DG. Risk factors for psychoses secondary to temporal lobe epilepsy: a systematic review. J Neuropsychiatry Clin Neurosci 2014; 26: 5-23. http://dx.doi.org/10.1176/appi.neuropsych.12120403

[40] Samer CF, Ing Lorenzini K, Rollason V, Daali Y, Desmeules JA. Applications of CYP450 testing in the clinical setting. Mol Diagn Ther 2013; 17: 165-84. http://dx.doi.org/10.1007/s40291-013-0028-5

[41] Piana C, de Jesus Antunes N, Della Pasqua O. Implications of pharmacogenetics for the therapeutic use of antiepileptic drugs. Expert Opin Drug Metab Toxicol 2014; 10: 341-58. http://dx.doi.org/10.1517/17425255.2014.872630

[42] De Kuijper G, Mulder H, Evenhuis H, Scholte F, Visser F, Hoekstra PJ. Determinants of physical health in individuals with intellectual disability who use long-term antipsychotics. Res Develop Disabil 2013a; 34: 2799-809.

http://dx.doi.org/10.1016/j.ridd.2013.05.016 
[43] Shogren KA. Considering context: an integrative concept for promoting outcomes in the intellectual disability field. Intellect Dev Disabil 2013; 51: 132-7. http://dx.doi.org/10.1352/1934-9556-51.2.132

[44] Gualtieri CTH. Brain injury and mental retardation: psychopharmacology and neuropsychiatry. Philadelphia: Lippincott Williams \& Wilkins; 2002.

[45] Verhoeven WMA, Tuinier S. Cyclothymia or unstable mood disorder? A systematic treatment evaluation with valproic acid. J Appl Res Intellect Disabil 2001; 14: 147-54. http://dx.doi.org/10.1046/j.1468-3148.2001.00063.x

[46] Pinborough-Zimmerman J, Satterfield R, Miller J, Bilder D, Hossain S, McMahon W. Communication disorders: prevalence and comorbid intellectual disability, autism, and emotional/behavioural disorders. Am J Speech Lang Pathol 2007; 16: 359-67.

http://dx.doi.org/10.1044/1058-0360(2007/039)

[47] Boyle CA, Boulet S, Schieve LA, et al. Trends in the prevalence of developmental disabilities in US children, 1997-2008. Pediatrics 2011; 127: 1034-42. http://dx.doi.org/10.1542/peds.2010-2989

[48] Yang L, Zhan GD, Ding JJ, et al. Psychiatric illness and intellectual disability in the Prader-Willi syndrome with different molecular defects - a meta analysis. Plos One 2013; 8: e72640.

http://dx.doi.org/10.1371/journal.pone.0072640

[49] Verhoeven WMA, Egger JIM, Ahmed AIA, Kremer BPH, Vermeer S, van de Warrenburg BPC. Cerebellar cognitive affective syndrome and autosomal recessive spastic ataxia of Charlevoix-Saguenay: a report of two male sibs. Psychopathology 2012; 45: 193-9. http://dx.doi.org/10.1159/000331319

[50] Shprintzen RJ. Velo-Cardio-Facial Syndrome: a distinctive behavioural phenotype. Ment Retard Dev Disabil Res Rev 2000; 6: $142-7$.

http://dx.doi.org/10.1002/1098-2779(2000)6:2<142::AIDMRDD9>3.0.CO;2- $\mathrm{H}$

[51] Baker K, Vorstman JAS. Is there a core neuropsychiatric phenotype in 22q11.2 deletion syndrome? Curr Opin Neurol 2012; 25: 131-7.

http://dx.doi.org/10.1097/WCO.0b013e328352dd58

[52] Tang SX, Yi JJ, Calkins ME, et al. Psychiatric disorders in 22q11.2 deletion syndrome are prevalent but not undertreated. Psychol Med 2014; doi:10.1017

[53] Niklasson L, Gillberg C. The neuropsychology of 22q11 deletion syndrome. A neuropsychiatric study of 100 individuals. Res Dev Disabil 2010; 31: 185-94.

http://dx.doi.org/10.1016/j.ridd.2009.09.001

[54] Verhoeven WMA, Egger JIM, Tuinier S. Thoughts on the behavioural phenotypes in Prader-Willi syndrome and velocardio-facial syndrome: a novel approach. Acta Neuropsychiatr 2007; 19: 244-50.

http://dx.doi.org/10.1111/j.1601-5215.2007.00202.x

[55] Schneider M, van der Linden M, Menghetti S, Glaser B, Debbané $M$, Eliez $S$. Predominant negative symptoms in 22q11.2 deletion syndrome and their associations with cognitive functioning and functional outcome. J Psychiatr Res 2014; 48: 86-93.

http://dx.doi.org/10.1016/j.jpsychires.2013.10.010

[56] Zaleski C, Bassett AS, Tam K, Shugar AL, Chow EWC, McPherson E. The co-occurrence of early onset Parkinson disease and 22q11.2 deletion syndrome. Am J Med Genet 2009; 149A: 525-8.

http://dx.doi.org/10.1002/ajmg.a.32650

[57] Butcher NJ, Kiehl TR, Hazrati LN, et al. Association between early-onset Parkinson disease and 22q11.2 deletion syndrome. Identification of a novel genetic form of Parkinson Disease and its clinical implications. JAMA Neurol 2013; 70: 1359-66.

http://dx.doi.org/10.1001/jamaneurol.2013.3646
[58] McHugh L, Barnes-Holmes $Y$, Barnes-Holmes D. Perspective-taking as relational responding: a developmental profile. Psychol Rep 2004; 54: 115-44.

[59] Vilardaga R, Estévez A, Levin ME, Hayws SC. Deictic relational responding, empathy, and experiential avoidance as predictors of social anhedonia: further contributions from relational frame theory. Psychol Rec 2012; 62: 409-32.

[60] Fagerberg CR, Graakjaer J, Heinl UD, et al. Heart defects and other features of the 22q11 distal deletion syndrome. Eur J Med Genet 2013; 56: 98-107.

http://dx.doi.org/10.1016/i.ejmg.2012.09.009

[61] Wieser R, Fritz B, Ullmann R, et al. Novel rearrangement of chromosome band 22q11.2 causing 22q11 microdeletion syndrome-like phenotype and rhabdoid tumor of the kidney. Hum Mutat 2005; 26: 78-83. http://dx.doi.org/10.1002/humu.20195

[62] Verhoeven W, Egger J, Brunner H, de Leeuw N. A patient with a de novo distal 22q11.2 microdeletion and anxiety disorder. Am J Med Genet 2010; 155A: 392-7.

[63] Koolen DA, Vissers LELM, Pfundt R, de Leeuw $N$, et al. A new chromosome 17q21.31 microdeletion syndrome associated with a common inversion polymorphism. Nat Genet 2006; 38: 999-1001. http://dx.doi.org/10.1038/ng1853

[64] Zollino M, Orteschi D, Murdolo M, et al. Mutations in KANSL1 cause the 17q21.31 microdeletion syndrome phenotype. Nat Genet 2012; 44: 636-8.

http://dx.doi.org/10.1038/ng.2257

[65] Koolen DA, Sharp AJ, Hurst JA, et al. Clinical and molecular delineation of the 17q21.31 microdeletion syndrome. J Med Genet 2008; 45: 710-20. http://dx.doi.org/10.1136/jmg.2008.058701

[66] Egger JIM, Wingbermühle E, Verhoeven WMA, et al. Hypersociability in the behavioral phenotype of $17 q 21.31$ microdeletion syndrome. Am J Med Genet 2013; 161A: 21-6.

[67] Kleefstra T, Smidt M, Banning MJG, et al. Disruption of the gene Euchromatin Histione Methyl Transferase 1 (EuHMTase 1) is associated with the $9 \mathrm{q} 34$ subtelomeric deletion syndrome. J Med Genet 2005; 42: 299-306.

http://dx.doi.org/10.1136/jmg.2004.028464

[68] Kleefstra T, Brunner HG, Amiel J, et al. Loss-of-function mutations in Euchromatin Histione Methyl Transferase 1 (EHMT1) cause the 9q34 subtelomeric deletion syndrome. Am J Hum Genet 2009; 79: 370-7.

http://dx.doi.org/10.1086/505693

[69] Yatsenko SA, Brundage EK, Roney EK, Cheung SW, Chinault AC, Lupski JR. Molecular mechanisms for subtelomeric rearrangements associated with the 9q34.3 microdeletion syndrome. Hum Mol Genet 2009; 18: 1924-36. http://dx.doi.org/10.1093/hmg/ddp114

[70] Willemsen MH, Vulto-van Silfhout, Nillisen WM, et al. Update on Kleefstra syndrome. Mol Syndromol 2011; 2: 202-12.

[71] Verhoeven WMA, Kleefstra T, Egger JIM. Behavioral phenotype in the $9 q$ subtelomeric deletion syndrome: a report about two adult males. Am J Med Genet 2009; 153B: 536-41.

[72] Verhoeven WMA, Egger JIM, Vermeulen K, van de Warrenburg BPC, Kleefstra T. Kleefstra syndrome in three adult patients: further delineation of the behavioural and neurological phenotype shows aspects of a neurodegenerative course. Am J Med Genet 2011; 155A: 2409-15. http://dx.doi.org/10.1002/ajmg.a.34186

[73] Starkstein SE, Leentjes AFG. The nosological position of apathy in clinical practice. J Neurol Neurosurg Psychiatry 2008; 79: 1088-92.

http://dx.doi.org/10.1136/jnnp.2007.136895

[74] Fink M. Rediscovering catatonia: the biography of a treatable syndrome. Acta Psychiatr Scand 2013; 127(Suppl 441): 1-47. http://dx.doi.org/10.1111/acps. 12038 
[75] Hallervorden J, Spatz $H$. Eigenartige Erkrankung im extrapyramidalen System mit besonderer Beteiligung des Globus pallidus und der Substantia nigra. Z Gesammte Neurol Psychiatr 1922; 79: 254-302.

http://dx.doi.org/10.1007/BF02878455

[76] Van Craenenbroeck A, Gebruers M, Martin JJ, Cras PC. Hallervorden-Spatz disease: historical case presentation in the spotlight of nosological evolution. Mov Disord 2010; 25: 2486-92.

http://dx.doi.org/10.1002/mds.23217

[77] Kruer MC, Boddaert N, Schneider SA, et al. Neuroimaging features of neurodegeneration with brain iron accumulation. Am J Neuroradiol 2012; 33: 407-14.

http://dx.doi.org/10.3174/ajnr.A2677

[78] Saitsu H, Nishimura T, Muramatsu K, et al. De novo mutations in the autophagy gene WDR45 cause static encephalopathy of childhood with neurodegeneration in adulthood. Nat Genet 2013; 45: 445-9.

http://dx.doi.org/10.1038/ng.2562

[79] Hayflick SJ, Kruer MC, Gregory A, et al. Beta-propeller protein-associated neurodegeneration: a new X-linked dominant disorder with brain iron accumulation. Brain 2013; 136: $1708-17$.

http://dx.doi.org/10.1093/brain/awt095

[80] Horvath R. Brain iron takes off: a new propeller protein links neurodegeneration with autophagy. Brain 2013; 136: 168791.

http://dx.doi.org/10.1093/brain/awt098

[81] Haack TB, Hogarth P, Gregory A, Prokisch H, Hayflick SJ. BPAN: the only X-linked dominant NBIA disorder. Int Rev Neurobiol 2013; 110: 85-90. http://dx.doi.org/10.1016/B978-0-12-410502-7.00005-3

[82] Verhoeven WM, Egger JI, Koolen D, et al. Beta-propeller protein-associated neurodegeneration (BPAN), a rare form of NBIA: novel mutations and neuropsychiatric phenotype in three adult patients. Parkinsonism Relat Disord 2014; 20: 332-6.

http://dx.doi.org/10.1016/j.parkreldis.2013.11.019

[83] Sedel F, Baumann N, Turpin JC, Lyon-Caen O, Sandubray JM, Cohen D. Psychiatric manifestations revealing inborn errors of metabolism in adolescents and adults. J Inherit Metab Dis 2007; 30: 631-41.

http://dx.doi.org/10.1007/s10545-007-0661-4

[84] Vanier MT. Niemann-Pick disease type C. Orphanet J Rare Dis 2010; 5: 16.

http://dx.doi.org/10.1186/1750-1172-5-16

[85] Verhoeven WMA, Csepán R, Marcelis CLM, et al. Sanfilippo $B$ in an elderly female psychiatric patient: a rare but relevant diagnosis in presenile dementia. Acta Pychiatr Scand 2010; 122: $162-5$. http://dx.doi.org/10.1111/j.1600-0447.2009.01521.x

[86] Wijburg FA, Wegrzyn G, Burton BK, Tylki-Szymaríska A. Mucopolysaccharidosis type III (Sanfilippo syndrome) and misdiagnosis of idiopathic developmental delay, attention deficit/hyperactivity disorder or autism spectrum disorder. Acta Paediatr 2013; 102: 462-70.

http://dx.doi.org/10.1111/apa.12169

[87] Meins W. Wie werden geistig behinderte Erwachsene mit depressiven Störungen psychopharmakologisch behandelt? Nervenarzt 1996; 67: 216-8.

[88] Engel C, Szrama E, Hässler F. Die psychopharmakologische Therapie von Menschen mit geistiger Behinderung. Ein Vergleich der Jahre 1991 und 2005. Psychiat Prax 2010; 37: 391-6.

http://dx.doi.org/10.1055/s-0030-1248500

[89] Paton C, Flynn A, Shingleton-Smith A, et al. Nature and quality of antipsychotic prescribing practice in UK psychiatry of intellectual disability services. J Intellect Disabil Res 2011; 55: 665-74.

http://dx.doi.org/10.1111/j.1365-2788.2011.01421.x
[90] Sohanpal SK, Deb S, Thomas C, Soni R, Lenôtre L, Unwin $G$. The effectiveness of antidepressant medication in the management of behavioural problems in adults with intellectual disabilities: a systematic review. J Intellect Disabil Res 2007; 51: 750-65 http://dx.doi.org/10.1111/j.1365-2788.2006.00935.x

[91] Deb S, Chaplin R, Sohanpal S, Unwin G, Soni R, Lenotre L. The effectiveness of mood stabilizers and antiepileptic medication for the management of behaviour problems in adults with intellectual disability: a systematic review. J Intellect Disabil Res 2008; 52: 107-13.

[92] Erickson CA, Stigler KA, Posey DJ, McDougle CJ. Aripiprazole in autism spectrum disorders and fragile $X$ syndrome. Neurotherapeutics 2010; 7: 258-63. http://dx.doi.org/10.1016/j.nurt.2010.04.001

[93] Politte L, McDougle C. Atypical antipsychotics in the treatment of children and adolescents with pervasive developmental disorders. Psychopharmacology 2014; 231: 1023-36. http://dx.doi.org/10.1007/s00213-013-3068-y

[94] Jesner OS, Aref-Adib M, Coren E. Risperidone for autism spectrum disorder. Cochrane Database Syst Rev 2010; 1: CD005040.

[95] Ching H, Pringsheim T. Aripiprazole for autism spectrum disorders (ASD) Cochrane Database Syst Rev 2012; 5: CD009043.

[96] Thomson A, Maltezos S, Paliokosta E, Xenitidis K. Risperidone for attention-deficit hyperactivity disorder in people with intellectual disabilities. Cochrane Database Syst Rev 2010; 2: CD007011.

[97] Bolea-Alamañac B, Nutt DJ, Adamou M, et al. Evidence based guidelines for the pharmacological management of attention deficit hyperactivity disorder: Update on recommendations from the British association for psychopharmacology. J Psychopharmacol 2014; 28: 179-203. http://dx.doi.org/10.1177/0269881113519509

[98] Loy JH, Merray SN, Hetrick SE, Stasiak K. Atypical antipsychotics for disruptive behaviour disorders in children and youths. Cochrane Database Syst Rev 2012; 9: CD008559.

[99] Pringsheim T, Gorman D. Second-generation antipsychotics for the treatment of disruptive behaviour disorders in children: a systematic review. Can J Psychiatry 2012; 57: 722-7.

[100] De Hert M, Dobbelaere M. Sheridan EM, Cohen D, Correll $\mathrm{CU}$. Metabolic and endocrine adverse effects of secondgeneration antipsychotics in children and adolescents: a systematic review of randomized, placebo controlled trials and guidelines for clinical practice. Eur Psychiatry 2011; 26: 144-158.

http://dx.doi.org/10.1016/j.eurpsy.2010.09.011

[101] Mitchell AJ, Vancampfort D, Sweers K, van Winkel R, Yu W, de Hert M. Prevalence of metabolic syndrome and metabolic abnormalities in schizophrenia and related disorders. A systematic review and meta-analysis. Schizophr Bull 2013; 39: 306-18.

http://dx.doi.org/10.1093/schbul/sbr148

[102] Leonhard K. Classification of endogenous psychoses and their differentiated etiology. $2^{\text {nd }}$ ed. Wien: Springer Verlag; 1999.

http://dx.doi.org/10.1007/978-3-7091-6371-9

[103] Clarke D, Boer H, Webb T, et al. Prader-Willi syndrome and psychotic symptoms: I. Case descriptions and genetic studies. J Intell Disabil Res 1998; 42: 440-50. http://dx.doi.org/10.1046/j.1365-2788.1998.4260440.x

[104] Verhoeven WMA, Curfs LMG, Tuinier S. Prader-Willi syndrome and cycloid psychosis. J Intellect Disabil Res 1998; 42: 455-62. http://dx.doi.org/10.1046/j.1365-2788.1998.4260455.x

[105] Vogels A, Matthijs G, Legius E, Devriendt K, Fryns JP. Chromosome 15 maternal uniparental disomy and psychosis in Prader-Willi syndrome. J Med Genet 2003; 40: 72-3. http://dx.doi.org/10.1136/jmg.40.1.72 
[106] Verhoeven WMA, Tuinier S, Curfs LMG. Prader-Willi syndrome: the psychopathological phenotype in uniparental disomy. J Med Genet 2003; 40: e112. http://dx.doi.org/10.1136/jmg.40.10.e112

[107] Verhoeven WMA, Tuinier S. Prader-Willi syndrome: atypical psychoses and motor dysfunctions. Int Rev Neurobiol 2006; 72: 119-30.

http://dx.doi.org/10.1016/S0074-7742(05)72007-9

[108] Larson FV, Whittington J, Webb T, Holland AJ. A longitudinal follow-up study of people with Prader-Willi syndrome with psychosis and those at increased risk of developing psychosis due to genetic subtype. Psychol Med 2013; doi:10.1017.

[109] Tyrer P, Oliver-Africano P, Ahmed Z, et al. Risperidone, haloperidol, and placebo in the treatment of aggressive challenging behaviour in patients with intellectual disability: a randomized controlled study. Lancet 2008; 371: 57-63. http://dx.doi.org/10.1016/S0140-6736(08)60072-0

[110] Ahmed Z, Fraser W, Kerr MP, et al. Reducing antipsychotic medication in people with a learning disability. $\mathrm{Br} J$ Psychiatry 2000; 176: 42-6.

http://dx.doi.org/10.1192/bjp.176.1.42

[111] De Kuijper G, Mulder H, Evenhuis H, Visser F, Hoekstra PJ. Effects of controlled discontinuation of long-term used antipsychotics on weight and metabolic parameters in individuals with intellectual disability. J Clin Psychopharmacol 2013b; 33: 520-4.

http://dx.doi.org/10.1097/JCP.0b013e3182905d6a

[112] De Kuijper G, Evenhuis H, Minderaa RB, Hoekstra PJ. Effects of controlled discontinuation of long-term used antipsychotics for behavioural symptoms in individuals with intellectual disability. J Intellect Disabil Res 2014; 58: 71-83. http://dx.doi.org/10.1111/j.1365-2788.2012.01631.x

[113] Caley CF. Interpreting and applying CYP450 genomic test results to psychotropic medications. J Pharm Pract 2011; 24: 439-66. http://dx.doi.org/10.1177/0897190011422873

[114] Ravyn D, Ravyn V, Lowney R, Nasrallah HA. CYP450 pharmacogenetic treatment strategies for antipsychotics: a review of the evidence. Schizophr Res 2013; 149: 1-14. http://dx.doi.org/10.1016/j.schres.2013.06.035

[115] Hassiotis A, Robotham D, Canagasabey A, et al. Randomized, single-blind, controlled trial of a specialist behaviour therapy team for challenging behaviour in adults with intellectual disabilities. Am J Psychiatry 2009; 166: 1278-85. http://dx.doi.org/10.1176/appi.ajp.2009.08111747

[116] Oliver-Africano P, Murohy D, Tyrer P. Aggressive behaviour in adults with intellectual disability. Defining the role of drug treatment. CNS Drugs 2009; 23: 903-13. http://dx.doi.org/10.2165/11310930-000000000-00000

[117] Sturmey P. Treatment of psychopathology in people with intellectual and other disabilities. Can J Psychiatry 2012; 57: 593-600.

[118] Willner P, Rose J, Jahoda A, et al. Group-based cognitivebehavioural anger management for people with mild to moderate intellectual disabilities: cluster randomised controlled trial. Brit J Psychiatry, 2013; 203: 288-96. http://dx.doi.org/10.1192/bjp.bp.112.124529

[119] Gould E, Trabox J, O'Hora D, Noone S, Bergstrm R. Teaching children with autism a basic component skill of perspective thinking. Behav Intervent 2011; 26: 50-66. http://dx.doi.org/10.1002/bin.320

[120] Wingbermühle E. Egger JIM, Verhoeven WMA, van den Burgt I, Kessels RPC. Affective functioning and social cognition in Noonan syndrome. Psychol Med 2012; 42: 419-26. http://dx.doi.org/10.1017/S0033291711001115

[121] Janssen G, De Mey H, Hendriks A, et al. Assessing deictic relational responding in adults with social anxiety disorder: evidence of perspective taking difficulties. Psychol Rec 2014; 64, 21-9. http://dx.doi.org/10.1007/s40732-014-0013-3

[122] Gladson S, Clarke DJ. Clozapine treatment of psychosis associated with velo-cardio-facial syndrome: benefits and risks. J Intellect Disabil Res 2005; 49: 567-70. http://dx.doi.org/10.1111/j.1365-2788.2005.00708.x

[123] Briegel W. Deletion 22q11.2 und schizophrene Störungen im Kindes- und Jugendalter. Z. Kinder-Jugendpsychiatr Psychother 2007; 35: 353-8. http://dx.doi.org/10.1024/1422-4917.35.5.353

[124] Krahn LE, Maraganore DM, Michels VV. Childhood-onset schizophrenia associated with parkinsonism in a patient with a microdeletion of chromosome 22. Mayo Clin Proc 1998; 73: 956-9.

http://dx.doi.org/10.4065/73.10.956

[125] Yacoub A, Aybar M. Response to clozapine in psychoses associated with velo-cardio-facial syndrome. Psychiatry 2007; 4: 14.

[126] Gagliano A, Masi G. Clozapine-aripiprazole association in a 7-year-old girl with schizophrenia: clinical efficacy and successful management of neutropenia with lithium. J Child Adolesc Psychopharmacol 2009; 19: 595-8.

http://dx.doi.org/10.1089/cap.2009.0012

[127] Sporn A, Addington A, Reiss Al, et al. 22q11 Deletion syndrome in childhood onset schizophrenia: an update. Mol Psychiatry 2004; 9: 225-6. http://dx.doi.org/10.1038/sj.mp.4001477

[128] Müller UJ, Fellgiebel A. Successful treatment of long-lasting psychosis in a case of 22q11.2 deletion syndrome. Pharmacopsychiatry 2008; 41: 158-9. http://dx.doi.org/10.1055/s-2008-1062700

[129] Lin CE, Hwang KS, Hsieh $\mathrm{PH}$, Chi CH. Treatment of schizophreniform disorder by aripiprazole in a female adolescent with 22q11.2 deletion syndrome. Prog Neuropsychopharmacol Biol Psychiatry 2010; 34: 1141-3. http://dx.doi.org/10.1016/j.pnpbp.2010.05.011

[130] Carandang CG, Scholten MC. Metyrosine in psychosis associated with 22q11.2 deletion syndrome: case report. J Child Adolesc Psychopharmacol 2007; 17: 115-20. http://dx.doi.org/10.1089/cap.2006.0013

\section{DOI: http://dx.doi.org/10.6000/2292-2598.2014.02.02.1}

(c) 2014 Verhoeven et al.; Licensee Lifescience Global.

This is an open access article licensed under the terms of the Creative Commons Attribution Non-Commercial License (http://creativecommons.org/licenses/by-nc/3.0/) which permits unrestricted, non-commercial use, distribution and reproduction in any medium, provided the work is properly cited. 